\title{
ROUSSEAU E A ADMINISTRAÇÃO DOS BENS
}

Luiz Felipe Netto de Andrade e Silva SAHD ${ }^{1}$

n RESUMO: O texto salienta a importância das regras da arte de governar no pensamento político de Rousseau, em especial as regras que mantêm a máquina administrativa funcionando.

n PALAVRAS-CHAVE: Soberania popular; economia; propriedade privada; teoria fiscal; luxo.

Não é minha intenção polemizar sobre o lugar ocupado por Rousseau na história do pensamento econômico, ${ }^{2}$ nem mesmo se ele ignorou a grande questão de seu tempo, o surgimento da burguesia industrial, ${ }^{3}$ mas apenas determinar os contornos de um problema incontornável para a política: como é possível aliar os interesses dos indivíduos com as necessidades materiais do Estado. Em outros termos, como aliar os bens, a liberdade e a vida das pessoas com a intervenção obrigatória do poder estatal que levanta fundos para garantir a sua própria manutenção. Como conciliar, porém, as garantias individuais dos membros do corpo político com a intromissão das instituições públicas nos limites da esfera do privado, deslocando-se livremente entre os espaços social e familiar? A solução desse problema, a meu ver, envolve uma abordagem dos modos legítimos de arrecadação fiscal que o governo pode cobrar dos cidadãos contribuintes. Quais são os limites da atuação do poder executivo na legis-

\footnotetext{
1 Departamento de Filosofia - Universidade Federal de Uberlândia - MG - Brasil

2 Para o historiador do pensamento econômico Joseph A. Schumpeter (1954), Rousseau não escreveu nenhuma linha sobre economia, não merecendo, por isso, um lugar na história dessa ciência. 3 Posição assumida por Derathé, 1964, p.LXXIX.
} 
lação tributária do país: os governantes podem por meio de legislação específica agir segundo os seus interesses políticos, ou devem respeitar as leis fundamentais da nação criadas pela assembléia popular soberana, a vontade geral? De fato, respondê-la requer o apreço de três temas para Rousseau, a crítica à noção de progresso, as dificuldades engendradas pela noção de propriedade privada e a teoria fiscal.

$\mathrm{O}$ artigo que o leitor tem em mãos é fruto de uma suspeita e resulta numa hesitação. Se Rousseau realmente escreveu algo de importante no campo econômico, as suas soluções responderam de fato às exigências cobradas pelo capitalismo emergente? Ou, ao invés disso, ficaram aquém da demanda prescrita pelos avanços da industrialização que começa a surgir nos horizontes da burguesia? A hesitação depende mais das circunstâncias históricas desfavoráveis e pouco claras para uma avaliação positiva dos feitos do capitalismo, do que propriamente de eventuais conceitos emitidos por Rousseau que pudessem ser acusados de anacrônicos, uma espécie de pregação quase mítica do regresso às origens idílicas do estado de natureza. Poderia o autor de Genebra, filho abandonado pela cidade à qual devotou amor incondicional, ${ }^{4}$ escapar às limitações e ambigüidades, frutos do peculiar condicionamento histórico, escapar à dicotomia reproduzida pelas noções políticas que mantêm o homem dilacerado entre dois pólos de uma divisão insuperável? Dicotomia reprodutora da repartição igualitária da propriedade privada, certamente, mas cuja base econômico-social continua a se basear numa economia mercantil simples ainda pré-capitalista? Contudo, se a teoria então existia dessa maneira e era regulamentada devidamente pela conjuntura, isso implica reconhecer que existia um grande contingente de idéias que não se inseriam na figura da tradição liberal, cujos contornos devemos delinear. Ora, talvez aí esteja o essencial da crítica rousseauniana e não é preciso muita argúcia interpretativa para reconhecer isso, apenas um pouco de esforço e boa vontade.

Nesse sentido, salientei apenas aquilo que julguei pertinente para esclarecer a trama dessa crítica, sem pretender também, nas análises positivas que procuro realizar, esgotar o tema da problemática rousseaniana. A minha perspectiva é modesta, se insere tão somente no tratamento das questões fiscais e sua legitimidade.

\footnotetext{
4 Cf. o comentário de Guy Besse (1988, p.264) sobre a experiência real vivida por Rousseau: haveria um paralelo entre a teoria e a condição do cidadão Jean-Jacques que ama o seu país. "Genebra indiferente, pergunta o comentador, não seria o amor infeliz de Jean-Jacques?".
} 


\section{Um corpo permanente}

Antes, porém, de dar prosseguimento ao tema deste artigo, é preciso fazer um breve desvio para estabelecer as marcas indeléveis deixadas no político pela teoria da arte de governar e suas regras da manutenção do corpo político.

Para Rousseau, se o poder soberano nas repúblicas está nas mãos da assembléia popular, o governo encontra-se em poder dos magistrados, ele é "pura e simplesmente uma comissão (...) na qual, como meros funcionários do soberano, os governantes exercem em seu nome o poder de que ele os fez depositários, e que pode limitar, modificar e retomar quando lhe aprouver" (Rousseau, 1964b, p.396). Em outra passagem do Contrato Social, Rousseau ressalta por meio de uma metáfora orgânica a diferença e primazia do legislativo: "O poder legislativo é o coração do Estado, o poder executivo é o seu cérebro, que dá movimento a todas as partes. O cérebro pode ficar paralisado e o indivíduo continuar a viver ainda. Um homem se torna imbecil e continua vivo: mas assim que o coração cessa suas funções, o animal morre" (Rousseau, 1964b, p.424). Assim, o processo de formação da vontade geral na assembléia legislativa encontra seu complemento no governo, pois ele tem força necessária para levá-la a efeito e aplicá-las em atos particulares. O governo está encarregado da manutenção da liberdade, tanto civil quanto política (Rousseau, 1964b, p.396).

Portanto, de acordo com Rousseau, os indivíduos que são cidadãos exercitam sua soberania coletivamente sempre que se reúnem na assembléia geral, convocada de tempos em tempos, e estão habitualmente sujeitos a um governo que é um corpo permanente, incumbido de executar as leis e da administração diária. Desse modo, temos duas relações de subordinação: a subordinação do governo aos cidadãos como corpo, e a do súdito ao governo.

Se a soberania pertence ao povo, que adquire realidade na medida em que exerce o poder legislativo, o executivo deveria ser uma extensão de suas prerrogativas. Contudo, alerta Rousseau, não é bem isso o que acontece na prática:

O poder legislativo consiste em duas coisas inseparáveis: fazer as leis e mantê-las; isto é, ter inspeção sobre o poder executivo. Não existe Estado no mundo em que o soberano não tenha esta inspeção. Sem isto toda ligação, toda subordinação que falte entre esses dois poderes, o último não dependeria jamais do primeiro; a execução não teria nenhuma relação necessária às leis; a Lei seria apenas uma palavra, e a palavra não significaria nada (Rousseau, 1964d, p.826). 
Se a supervisão sobre o executivo torna-se cada vez menos velada pelo corpo dos cidadãos; se o governo torna-se cada vez mais independente do poder legislativo, então, ocorrerá um "afrouxamento da soberania", cujas conseqüências serão desastrosas para o corpo político como um todo. Bastaria um efeito muito comum entre os países densamente povoados, a concentração da autoridade governamental, para que este "afrouxamento da soberania" se efetivasse obedecendo a uma lei positiva na política, isto é, justificada pela evidência empírica. Sobre a insistência de Rousseau na concentração da autoridade quando a população é grande, ele acrescenta:

Acabo de provar que o governo se torna mais fraco em proporção ao aumento do número de magistrados; e antes disso, provei que quanto maior a população do Estado, maior deve ser a força repressiva do governo. Disto se segue que o número relativo de magistrados para o governo deveria estar na proporção inversa àquela dos súditos para a soberania. Isto é, quanto maior o Estado, mais concentrado seu governo deve ser, de modo que o número de chefes diminua na medida em que o tamanho da população aumente (Rousseau, 1964b, p.402).

Na Carta da Montanha, colhemos ainda a indicação preciosa sobre a evidência empírica do "afrouxamento da soberania":

O princípio que determina as várias formas de governo depende do número de membros de que cada um se constitui. Quanto menor o número mais forte o governo; quanto maior o número mais fraco o governo e desde que a soberania tenda sempre a diminuir, o governo tende sempre a aumentar o seu poder. Portanto, o corpo executivo deve sempre, a longo prazo, prevalecer sobre o legislativo; e, quando a lei é finalmente subordinada aos homens, nada mais resta senão senhores e escravos, e o Estado está destruído (Rousseau, 1964d, p.808).

Nessa brilhante síntese do conteúdo do Livro III do Contrato Social, encontramos formulados o diagnóstico e apontada a etiologia da degeneração do corpo político. Um progresso natural muda obrigatoriamente a forma de governo, isto é, o governo deve sofrer uma alteração segundo uma lógica alheia ao dever ser ético pressuposto no início do Contrato Social. Para Rousseau, a redação aqui é reveladora, este processo é marcado por leis que determinam o que "vai acontecer" e não o que "deveria acontecer”. Em última instância, Rousseau prediz a destruição do que ele próprio, como moralista, recomenda. 
Dessa maneira, muda-se a perspectiva de fundo do Contrato Social. A nova perspectiva não representa mais uma descrição esperançosa da República futura, mas uma análise da deterioração política. Rousseau não oferece uma receita de como fazer do governo de uma grande e complexa sociedade uma democracia, pelo contrário, ele insiste em demonstrar que uma população numerosa e uma atividade crescente do governo exigem crescente complexidade das relações que levam inevitavelmente à centralização da autoridade política em poucas mãos, o que ele considera como o oposto da democracia. Sob o governo, ressalta inequivocamente o autor, o homem deve necessariamente ser controlado.

Essa mudança aparente de atitude não causa estranheza, uma vez que a lei fundamental de autoria do legislativo exigiria a sua particularização na forma de leis positivas e regulamentos de polícia. Um bom exemplo disso está nas regras da administração pública que mantêm o Estado funcionando: "Todos os deveres essenciais do governo", escreve Rousseau no "Esboço" do artigo Economia Política, "estão contidos neste pequeno número de artigos principais: 1. fazer observar as leis, 2. defender a liberdade, 3. manter os costumes, 4. e prover as necessidades públicas" (Rousseau, 1971, p.295). É preciso garantir estes instrumentos aos governantes como compromisso de governabilidade, sem eles as máximas da política tornam-se inviáveis e vacilantes. É preciso, pois, adequar o conteúdo dos artigos aos preceitos fundamentais do direito.

\section{Direito restrito de propriedade}

A partir do modelo esquematicamente descrito aqui, a idéia de corpo intermediário se constituiu como marca indelével do tratamento dispensado por Rousseau ao problema da manutenção do corpo político. Ele permitirá, também, dar novos contornos e coloridos às necessidades materiais do Estado, sem ferir "o mais sagrado de todos os direitos dos cidadãos" (Rousseau, 1964a, p.262-63), a propriedade privada. Como conciliar aquilo que se liga à conservação da vida e oferece uma garantia segura aos compromissos sociais, uma vez que os bens respondem pelos cidadãos, ${ }^{5}$ com a intervenção do Estado sobre as propriedades particulares, quando levanta fundos na tentativa de assegurar a sua manutenção,

\footnotetext{
5 Nesse sentido, "a propriedade é o verdadeiro fundamento da sociedade civil", só ela garante os compromissos, e sem os mesmos, seria fácil "fugir dos deveres e desprezar as leis" (Rousseau, 1964a, p.263).
} 
fixando leis de sucessão, testamentos e contratos? Ou seja, como assegurar a propriedade privada sem atacá-la? Situação embaraçosa, se consideramos a aparente ambigüidade assumida pela noção na economia da obra, ora negativa, no caso do Discurso sobre a Desigualdade, ora positiva, no caso do Contrato Social. ${ }^{6}$ Como resolver essa contradição? Dois caminhos são possíveis, o primeiro encontra-se no artigo Economia Politica ao retomar a solução proposta por Samuel Pufendorf, a natureza do direito de propriedade não se estende para além da vida de seu proprietário. Isso significa que, ao intervir, o Estado não restringe o direito, ao contrário, amplia o seu alcance: "prescreverlhe condições segundo as quais pode dispor deles, no fundo equivale menos a alterar aparentemente seu direito, do que, realmente, ampliá-lo de fato" (Rousseau, 1964a, p.263). Só a morte do proprietário - que representa o limite da posse legal sobre um bem qualquer - permite ao Estado dispor do bem conforme as suas prescrições legais, não antes disso. A segunda via está contida no Contrato Social, obra da fase madura do autor, e dá à propriedade um tratamento positivo, ou seja, um status jurídico que lhe concede legitimidade. Segundo Rousseau, só a partir do cumprimento das condições estabelecidas pelo pacto social, fica caracterizado o direito do primeiro ocupante sobre a posse da terra e definida a caracterização do proprietário pela sanção coletiva dos membros da nação (Rousseau, 1964b, p.365-66). Antes dessa aprovação coletiva não se pode dizer que exista efetivamente a propriedade, apenas a ocupação provisória do espaço comum e sua defesa pelo usurpador. Na falta do reconhecimento do soberano, o primeiro ocupante não é de fato o legítimo possuidor.

Mais do que uma diferença de percurso, as duas visões se completam, enquanto o Contrato Social lança as bases jurídicas da ação do Estado, diz quem participa de sua criação e irá se beneficiar dela, o artigo Economia Política propõe o modo mais adequado ao magistrado para executar as prescrições estabelecidas e conformes às leis da nação. Em

\footnotetext{
6 Lucio Colletti (1975, p.229) propõe uma leitura diferente dessa aparente ambigüidade rousseauniana. Ele rejeita que as contradições são motivadas pela influência de John Locke nos primeiros escritos de Rousseau como pensaram alguns comentadores. Colletti justifica a ambivalência do Discurso sobre a Desigualdade segundo a crítica simultânea de dois objetos tão distantes entre si como são a "sociedade civil", por um lado, e as instituições do Antigo Regime, por outro. Ainda que não desenvolva essa questão, a constatação é importante. Ela desloca o problema para um âmbito distinto do habitual: Rousseau não estaria interessado apenas em aceitar ou não uma tradição teórica, no caso, as influências políticas de Locke, mas em fazer uma crítica mais palpável das instituições do Antigo Regime (Contrato Social) e da sociedade civil (Discurso sobre a Desigualdade).
} 
última instância, a propriedade privada só é uma propriedade quando a usurpação inicial transforma-se "num verdadeiro direito", e isso só é conseguido através do contrato, a "base de todos os direitos", firmado por cada um dos membros da comunidade.

À luz dessas considerações, que significado devemos atribuir à crítica feita a John Locke no tocante à acumulação ilimitada dos bens?

Victor Goldschmidt demonstra que para legitimar a propriedade privada Rousseau se baseia na argumentação lockeana do Ensaio sobre o Governo Civil (Goldschmidt, 1983, p.526-35). A propriedade individual firma-se no trabalho, no esforço que o homem incorpora às coisas, ao sacá-las do estado em que as deixou a natureza. Esse esforço, que o indivíduo agrega aos bens, é o que permite a sua apropriação (Rousseau, 1969, p.332-33). Como Locke, Rousseau defende a possibilidade de retirar da natureza os bens que servem para a sua subsistência. E, como Locke em sua argumentação inicial, Rousseau recusa a sua monopolização (Rousseau, 1964b, p.366). Das três limitações iniciais estabelecidas pelo autor inglês ao direito de propriedade (trabalho, suficiência e utilização), o genebrino retoma apenas duas: a do trabalho e a da utilização.

Mas o objetivo de Locke consistia precisamente em eliminar essas limitações iniciais, estabelecidas pelo direito natural para salvaguardar a vida humana. Baseando-se sempre no direito natural, ele demonstra como é possível o estabelecimento de um direito ilimitado à propriedade: "E assim como os diferentes graus de esforço lograram conferir aos homens posses em proporções diferentes, essa invenção do dinheiro deu-lhes a oportunidade de continuá-las e aumentá-las" (Locke, 1996, $\S 48$, p.301). O dinheiro, por consentimento mútuo, permite a ampliação ilimitada da posse e do direito sobre ela. Além disso, a maior produtividade que gera a terra, apropriada individualmente, compensa a falta de terra disponível para os demais. Desta afirmação, Locke deduz que o incremento no produto total será distribuído entre todos, incluindo os homens que ficaram sem terras, que terão uma sensível melhora no nível de vida. Nenhum dano se causa, portanto, aos indivíduos restantes com a apropriação ilimitada; pelo contrário, o seu direito natural à subsistência permanece garantido mediante a relação salarial. ${ }^{7}$ Rousseau recusa a argumentação lockeana. A acumulação ilimitada não pressupõe nem o incremento generalizado de riqueza, nem permite aos pobres assegurar

7 Locke (1996, §41) diz: "E o Rei de um território amplo e fértil dele alimenta-se, veste-se e mora pior que um trabalhador diarista na Inglaterra". Apesar do exagero, a proposição oferece bem a medida do argumento. 
sua subsistência. A promessa dos ricos não pode ser cumprida (Rousseau, 1969, p.339). Diferentemente de Locke, Rousseau defende a propriedade limitada. A apropriação para ser legítima deve seguir um preceito importante: não conceber a defesa da propriedade desigual. Pelo contrário, tenaz defensor da sociedade de pequenos produtores, JeanJacques condena firmemente a relação salarial e a desigualdade social que fomenta (Rousseau, 1964b, p.391-92).

Reivindicação da propriedade privada, certamente, mas de uma propriedade limitada, segundo as necessidades básicas do indivíduo, que não engendram desigualdades nem dependência. Rousseau tenta conciliar a propriedade do produtor independente, que domina os meios de seu trabalho, com a proriedade comum e de uso. Ele não desconhece, porém, $\mathrm{o}$ alcance restrito de suas propostas, que se mostram antiquadas no instante em que as terras comunais estão em vias do desaparecimento completo em virtude da expropriação dos bens (Rousseau, 1964c, p.559). Mesmo assim, Rousseau insiste que o reforço e extensão dos bens comuns parecem o único meio para preservar a igualdade. Nesse sentido, fomentar a propriedade comum tem como objetivo debilitar a propriedade ilimitada, a concentração de terras (Rousseau, 1964e, p.924), confinando dentro de limites bem precisos os meios de sua aquisição sem que se coloque em perigo a igualdade da comunidade (Rousseau, 1964e, p.931).

Em suma, para reduzir e controlar a propriedade privada, Rousseau propõe aos córsicos uma série de medidas que impeçam seu crescimento. Fixando uma extensão máxima a cada lote de terra e impedindo a compra de terras fora de seu âmbito administrativo, o autor propõe dificultar o processo de diferenciação social no seio da comunidade aldeã córsica. As leis sucessoras devem buscar o mesmo objetivo, conclui Rousseau (Rousseau, 1964e, p.942).

Dessa forma, defender os bens comuns não implica a supressão da propriedade privada, mas evitar a concentração de terras, o desenvolvimento da desigualdade e o espólio dos camponeses pobres. Supõe, ainda, assegurar um pedaço de terra a cada camponês para manter a sua família. Significa, também, evitar a proletarização e a miséria dos migrantes nas periferias das cidades (Rousseau, 1964a, p.258).

Estas eram as linhas de força e o desenho teórico da leitura de Rousseau na sua pesquisa sobre a propriedade. Cabe-nos agora examinar essa interpretação, seus diversos enunciados, nas articulações com a manutenção da máquina administrativa e suas captações de recursos que pos- 
sibilitam, em última instância, o próprio reconhecimento da posse legal da propriedade.

\section{Uma teoria fiscal}

Definidas as novas condições de análise do direito de propriedade e as leis de sucessão, Rousseau parte para o estudo do tema central da sua tese: as finanças públicas que mantêm a máquina estatal funcionando e a sua captação de recursos, os impostos. A questão de fundo é complexa, além de ser premente para a teoria política. Como um requisito do estabelecimento da sociedade e de sua permanência, ela apresenta um forte componente histórico: tem início com a pressão fiscal na França, resultado das longas guerras de Luís XIV e do nascimento do debate sobre a reforma do fisco. ${ }^{8}$ Três personagens dominam a cena, são eles: Sébastien le Prestre, Marechal de Vauban; Pierre Le Pesant, senhor de Boisguilbert; e Charles-Irénée Castel, abade de Saint-Pierre. ${ }^{9}$ Mesmo sendo o menos conhecido dos três, o abade faz a crítica mais severa à política de Luís XIV e ao caráter arbitrário de sua prática financeira e fiscal. No Discours sur la polysynodie, ele chega mesmo a utilizar alguns termos pejorativos, como "vizirat", no intuito de reforçar a sua denúncia à excessiva autoridade dos ministros. Contudo, foi com seu projeto de reforma fiscal apresentado em 1717 e aprofundado em 1723 que atingiu o seu maior grau de influência no domínio das reformas práticas: a "taille tarifée" alcançou um relativo sucesso na região de Limoges. $\mathrm{O}$ abade adota, com essa reforma, certos procedimentos específicos na avaliação da riqueza do contribuinte, os bens prediais são medidos com o auxílio de uma unidade comum, denominada l'arpent, que rejeita a distinção entre os tipos de terra - boa, pobre e medíocre, por exemplo - como guia do produto a ser taxado. Além disso, ele descreve dezessete origens de riquezas do contribuinte que servem de base para sua declaração voluntária de fortuna.

Esse tipo de discussão sobre a necessidade de reformas do Estado, em muitos casos emocionante e apaixonada, não poderia passar desper-

\footnotetext{
8 Cf. sobre a crise fiscal no governo de Luís XIV e o seu motivo principal, as longas guerras de seu reinado, Bonney, 1996, p.319-30

9 Boisguilbert é tido por Joseph A. Schumpeter (1954, p.203-4) como o precursor dos fisiocratas.
} 
cebida a Rousseau. Os aspectos que dominam a controvérsia giram em torno de três pontos: a melhor técnica para sua aplicação ou imposto unificado e seguro; a moral com perceptores honestos; e a social com a repartição correta e justa do montante arrecadado. Porém, isso ainda não é tudo, além da pressão fiscal motivada pelas sucessivas guerras havia uma outra, tão prejudicial à saúde econômica do reino quanto esta, a profusão de taxas e impostos desiguais cobrados por regiões. A França, na época um grande país agrícola, estava submersa na maior desordem fiscal. Imperava, em seus domínios, um sistema complicado de arrecadação que favorecia, entre outras coisas, a sonegação e a prática comum da não declaração da existência dos bens com medo de ser taxado, e a ocorrência da cobrança fiscal, diferenciada, entre as províncias (Soboul, 1984, p.112). Isso tudo, e não poderia ser diferente, proporcionava um grande prejuízo aos cofres públicos cuja arrecadação era menor à esperada para saldar as receitas. Richard Bonney sintetiza bem o fenômeno histórico vivido pela França do século XVIII:

La France, par exemple, était un royaume fondé sur plusieurs économies, radicalement différentes les unes des autres, et fort peu intégrées les unes aux autres; les tentatives antérieures à 1789 de suppression des barrières douanières intérieures y ont abouti pour l'essentiel à des échecs. Ces systèmes économiques régionaux étaient, à leur tour, en relation avec d'autres économies régionales européennes (Bonney, 1996, p.XIII).

Nestes moldes, ficava impossível uma cobrança visando apenas à justiça social onde os ricos pagassem mais do que os pobres.

Se nas Considerações sobre a Polônia, Rousseau demonstra o seu ceticismo sobre o "interesse pecuniário", quando diz que "os sistemas de finanças fazem almas venais", pois "o emprego do dinheiro se desvia e se esconde; é destinado a uma coisa e empregado em outra" (Rousseau, 1964f, p.1005), no artigo Economia Política, entretanto, a sua postura parece estar mais próxima do programa de reformas. As críticas não são tão severas quanto nas Considerações, mas diluídas em noções suplementares com a intenção de conquistar um meio termo entre os anseios da acumulação e o desejo da distribuição igualitária da riqueza. Contudo, ainda assim as Considerações são um programa de reformas. Embora em muitos aspectos seja mais severo em suas críticas, o argumento central me parece o mesmo nas duas obras: como captar recursos para a manutenção do Estado, e se é possível fugir às suas artimanhas. Mas o que jus- 
tificaria a mudança de tom entre as obras? Uma resposta parcial é possível, desde que respeite os limites deste artigo.

O artigo Economia Política não teria um objeto particular, um Estado que necessitasse de mudanças, estando limitado por isso aos aspectos indiferentes das regras da arte de governar aplicadas de modo geral, indistintamente, entre todos os governos que almejam a boa administração da coisa pública. As Considerações, por sua vez, têm um objeto particular, o Estado polonês, e partem da premissa da não mudança de um povo ainda jovem e com poucos problemas. Para Rousseau, não se deve reformar aquilo que deve permanecer exatamente do mesmo modo, qualquer alteração significaria introduzir os germes da civilização, por conseguinte, principiar a degeneração do corpo político polonês. Nesse sentido, pôr em prática uma "economia justa e sábia" (Rousseau, 1964a, p.264), parece ser uma tarefa menos perturbadora no artigo Economia Política do que nas Considerações; esta última obra faria apenas algumas concessões sem jamais admitir completamente a importância da moeda para o erário: "As despesas públicas são inevitáveis, admito-o ainda; façam-nas com qualquer outra coisa que não o dinheiro" (Rousseau, 1964f, p.1006).

Ainda que o efeito das finanças públicas seja contestado, as instituições existentes permanecem nos moldes condenados por Rousseau. E o autor tem ciência disso, pois se vê obrigado a tratar dos "incômodos" recursos dos subsídios e dos impostos. É preciso instituir as regras relativas ao fisco. Para cumprir esta tarefa ele propõe uma ordem a ser seguida: primeiro, deve-se considerar a propriedade como base do pacto social e as suas exigências mais simples, cada um se obriga, tacitamente, a cotizar-se "para atender às necessidades públicas" (Rousseau, 1964a, p.270). Ao arcar com os custos voluntariamente, segundo um compromisso firmado a partir dos anseios inerentes aos seus desejos, o contribuinte legitima a tarifa e afasta qualquer possibilidade do pagamento se transformar em cobrança arbitrária. No entanto, o reconhecimento explícito não põe cada membro do corpo político como uma vontade particular, como poderia dar a entender a manifestação individual de cada uma delas; mas como uma vontade geral, através da pluralidade das vozes e conforme uma taxa proporcional à capacidade de cada um, para estar de acordo com o "espírito da confederação". Embora o cidadão não queira "pagar absolutamente nada", ele não deve permanecer "escravo de seu bolso" (Rousseau, 1964f, p.1010), mas agir como membro de um povo soberano e livre. Por isso, a aprovação popular é essencial para a fixação dos impostos e deve ser com todo o rigor respeitada. A esse respeito, a 
resposta enunciada pelo discurso rousseauniano é nítida e bastante clara, qual seja, existiria a impossibilidade de dominar completamente os excessos cometidos pelos governantes e a sonegação astutamente ajeitada pelos contribuintes sem um acordo mais amplo entre as partes envolvidas, um acordo que impusesse os limites dos direitos e deveres de cada um segundo a vontade geral soberana.

A melhor abordagem sobre o tema dos impostos, porém, está no artigo Economia Política. Ela fornece o núcleo central teórico em torno do qual se constrói a reflexão de Rousseau. Vejamos os seus desdobramentos. Há duas espécies de contribuição sobre os cidadãos, a real cobrada sobre as coisas e a pessoal recebida por "cabeça". "Dá-se, diz Rousseau, a ambas o nome de impostos ou de subsídios. Quando é o povo que fixa a soma estabelecida, chama-se subsídio; quando se estabelece todo o produto de uma taxa, trata-se de imposto" (Rousseau, 1964a, p.270). Respondendo à afirmação de Montesquieu sobre a taxa real ser mais conveniente à liberdade (Montesquieu, 1951, p.467), ${ }^{10}$ Rousseau após classificar os dois modos de contribuição defende o melhor, o que reunir os dois sistemas de cobrança em um só, conciliando a taxa por indivíduo proporcionalmente a seus meios de pagamento. Pois ela será a mais equitativa e conveniente a homens livres. Além disso, ela pode criar uma situação favorável contra a fraude: "É preciso que a taxação seja tão bem proporcionada, que o embaraço da fraude ultrapasse o lucro" (Rousseau, 1964f, p.1011). Não obstante, existem alguns empecilhos que tornam a sua aplicação difícil, apesar de todas as evidências que apontam na direção dessas justas proporções; são eles: a avareza, "o crédito e a fraude" (Rousseau, 1964f, p.1011). Mas o que forma a proporção desejada? Quais são os elementos de sua fundação? Segundo Rousseau, basta considerar três relações, a quantidade, o uso e a utilidade, para se chegar a um denominador comum entre as partes envolvidas no processo entre o contribuinte e a arrecadação pública (aerarium). A primeira, quem possui o dobro de bens paga duas vezes mais do que quem possui apenas uma propriedade, isto é, para os bens duplicados, imposto duplicado. A segunda, exige a distinção entre o estritamente necessário e o supérfluo com a intenção de taxar o excesso e o não imprescindível ao homem. E a terceira, refere-se às vantagens conseguidas na confederação social que protegem as posses dos ricos e deixam aos pobres a construção de uma miserável "choupana" erguida com as "próprias mãos" (Rousseau,

10 Cf. também a idéia de Montesquieu sobre a capitação ser o imposto mais "servil", embora cômodo e de baixo custo. Ele é comum "aos regimes sem liberdade política" (Bonney, 1996, p.184). 
1964a, p.271). A solução está em uma taxação maior dos ricos, pois eles devem pagar mais pelo usufruto dos benefícios adquiridos através do pacto social, como a garantia de suas propriedades e a manipulação da justiça referente às suas perdas. Sem esse aumento diferenciado, a perda do pobre torna-se irreparável (Rousseau, 1964a, p.272).

Para a política de Rousseau, é o efeito perverso que põe em xeque o fundamento último de sua filosofia, a liberdade do homem:

Tudo o que o povo paga, escreve o autor, perdeu para sempre, e fica ou volta às mãos dos ricos, e, como é somente aos homens que participam do governo ou aqueles que dele se aproximam, que, mais cedo ou mais tarde, passam os produtos dos impostos, eles têm, mesmo pagando a sua parte, um visível interesse em aumentá-los (Rousseau, 1964a, p.272).

Cria-se, assim, a pior forma de dependência cujos efeitos aprofundam irreversivelmente as desigualdades sociais, pois os ricos tornam-se mais ricos e os pobres aproximam-se ainda mais da miserável falta do mínimo necessário para o desenvolvimento da cidadania. Rousseau, em suma, parece reconhecer, nesta irregular distribuição das riquezas, que as sociedades são dilaceradas por todo tipo de desigualdades, desigualdades, aliás, que são vividas, pela maioria dos homens, como formas de violência.

A combinação das medidas acima anunciadas mostra que a divisão equitativa e proporcional deve ser imposta em virtude das diferenças sociais e do supérfluo dos bens. Ela é a única defesa contra as desigualdades e a reparação possível das injustiças do pacto social proposto pelos ricos aos pobres em troca do trabalho de governá-los (Rousseau, 1964a, p.273). Aliás, o pacto desigual e irregular do Discurso sobre a Desigualdade é visto por Rousseau como hipocrisia pura que não merece sequer a definição de contrato, mas a noção pejorativa, retomada do universo religioso, do pacto efetuado com o próprio demônio (Philonenko, 1984, p.258). Por outro lado, a combinação das medidas e sua aplicação evitam outro inconveniente ao Estado, a custosa sonegação fiscal. Só a taxa pessoal, infelizmente, tem a característica de não impedir que os indivíduos se subtraiam ao pagamento das contribuições devidas, pois, além de ser motivo de sonegação, é muito pesada e custosa, e pior, o dinheiro coletado está "sujeito a ser desviado de sua destinação" (Rousseau, 1964f, p.1011). Só a taxação sobre os domínios tem o poder de evitar uma situação como esta, muito embora o autor desautorizasse a cobrança sobre as terras. Nesse caso, o lavrador, ao se ver taxado proporcionalmente ao produto de seu campo, de seu trabalho, tende a deixar as terras que lhe per- 
tencem improdutivas, retirando apenas "o que precisa para viver" (Rousseau, 1964a, p.273). Ou seja, ele transformaria a sua propriedade, ao torná-la inculta, numa propriedade de subsistência. Para Rousseau, quem defende esta máxima está mais preocupado com a quantidade da produção e com a segurança da arrecadação fiscal do que com a comodidade do povo que governa. Está mais preocupado com as aparências do que em resolver o problema.

Dessa perspectiva, o imposto sobre as terras, a talha, como é denominado, só provoca danos ao país e incita a agricultura à indolência quando atrai para as cidades o dinheiro que deveria ser aplicado no campo. ${ }^{11}$ De fato, há uma perturbação na circulação monetária cuja conseqüência imediata é a quebra do livre jogo da concorrência com a diminuição brusca dos preços do trigo. O campo, segundo Rousseau, seria o grande prejudicado com um imposto dessa natureza, pois ele beneficiaria apenas o comércio e a indústria emergente com seus lucros exagerados. Os efeitos negativos, com o passar dos anos, se acumulariam a ponto de provocar o despovoamento das províncias e, no final dos tempos, a própria ruína do país (Rousseau, 1964a, p.273). Em outras palavras, a sentença de morte do paciente já moribundo e a imediata dissolução do Estado, que soçobra ao arbítrio da força, estariam invariavelmente decretadas. Assim, tudo o que desestabiliza o corpo político, tudo o que atenta à autoridade das leis, das crenças tradicionais e da religião, é sentido como força de dissolução e desintegração sociais. Afinal, ressalta o autor, quando há falhas na circulação das espécies motivadas pela concentração do dinheiro nas capitais e a destruição do preço justo entre as necessidades do agricultor e o valor de seu trigo, não é mais possível remediar o infortúnio da divisão sociopolítica. Ainda mais quando, a aparente vantagem do preço baixo, agrava os males sem que sejam percebidos. Na realidade, o preço baixo produz uma diminuição do produto no mercado até provocar a morte de várias pessoas de fome, ou a desnutrição em casos de crises passageiras. O próprio produtor, com a desvalorização de sua colheita, tem um dilema a resolver: ou paga o imposto real

\footnotetext{
11 Nas Considerações, porém, o autor parece retomar uma fórmula empregada tanto pelo marechal de Vauban como pelo abade de Saint-Pierre, quando atenua os efeitos negativos desse imposto se aplicado corretamente: "O melhor imposto, a meu ver, o mais natural, e que não está sujeito à fraude, é uma taxa proporcional sobre as terras e sobre todas as terras sem exceção". Quem produz deve pagar, conclui Rousseau. E nada escapa a esta cobrança: "todos os bens reais, terrestres, eclesiásticos e plebeus devem pagar igualmente, isto é, proporcionalmente à extensão e ao seu produto, seja qual for o proprietário" (Rousseau, 1964f, p.1011-12). Em suma, o princípio de universalidade e de justiça social devem nortear a sua aplicação, senão os prejuízos tornar-se-ão insuportáveis ao país.
} 
sobre suas mercadorias e repassa o seu custo ao preço final delas, ou absorve o prejuízo e passa a correr o risco da inadimplência (Rousseau, 1964a, p.275). A imposição fiscal excessiva manteria, dessa forma, a mercadoria num "preço vil", e a capitação sobre a terra seria, por isso mesmo, "um verdadeiro imposto sobre o seu produto" (Rousseau, 1964a, p.275). Mais justo do que o imposto direto sobre a terra, seria cobrar uma espécie de dízima do próprio produto. Esta seria recolhida na forma de "gêneros sobre a colheita", não em dinheiro (Rousseau, 1964f, p.1012).

O estadista digno do nome, ao tomar uma atitude diversa, elevaria os seus objetivos acima das questões relacionadas às finanças e mudaria o que poderia ser oneroso, como a carga tributária, em regulamentos de polícia mais úteis. A sua imagem de homem público estaria ancorada desse modo em ações que ultrapassariam o produto das taxas. Uma vez que a própria opinião pública se encarregaria de forjar uma representação duradoura e favorável dos políticos às voltas com realizações diferentes dos interesses dos grupos, facções ou partidos sectários, e que estivessem em plena sintonia com os benefícios da coletividade.

Por isso, a cobrança de impostos deve se limitar aos produtos de luxo ou coisas de "pura fruição" e isentar os produtos necessários. Sem esta precaução não se atingirá o fim desejado, a prevenção do aumento contínuo das desigualdades das fortunas, principal motivo da sujeição de uma multidão "de operários e de servidores úteis" aos ricos, e da multiplicação do número de pessoas ociosas na cidade e o despovoamento nos campos (Rousseau, 1964a, p.276). Tais impostos aliviam a pobreza cujo ônus recai exclusivamente sobre as riquezas. No entanto, é preciso estabelecer uma medida proporcional entre o preço dos produtos e o dinheiro que o sobrecarrega para não se transformar em fraude, mas na defesa dos indivíduos contra a sedução dos proveitos ilegítimos e do lucro desmedido. Donde a importância do tributo a ser pago por quem usa a coisa taxada e não por quem a vende. Assim sendo, Rousseau faz uma lista dos produtos visados pelo fisco:

Que se estabeleçam taxas grandes sobre os lacaios e as equipagens, sobre os espelhos, os lustres e o mobiliário, sobre os estofos e os dourados, os pátios e os jardins dos palácios, os espetáculos de todos os tipos, as profissões ociosas, como dançarinos, cantores, histriões; numa palavra, essa multidão de objetos de luxo, de diversão e de ociosidade que chocam, que tanto menos podem se esconder quanto o seu único uso é o de mostrar-se e que seriam inúteis se não fossem visíveis (Rousseau, 1964a, p.276). ${ }^{12}$ 
Como não há outra alternativa, que se cobre caro pelo usufruto dessas regalias, pois pensar na hipótese de o homem renunciar por livre e espontânea vontade ao gozo e prazeres que o luxo proporciona quando já desfrutou de suas delícias, é não conhecê-lo suficientemente. É mais provável a renúncia ao necessário para sobreviver e morrer de fome do que a aceitação da condição "vergonhosa" do revés consumista, principal fator de reconhecimento e distinção. O orgulho do homem consumidor vale mais, segundo Rousseau, do que a sua própria vida. Apesar da fórmula chocante e forçada, a vida pela aparência dos ornamentos, a tese rousseaniana produz um discurso incisivo cuja concisão é inegável, qual seja, a vaidade decorre do aumento das despesas como meio de distinção social, isto é, a opulência une-se ao preço dos produtos de luxo diferenciando o rico, que usufrui, e o pobre, que reconhece a diferença.

Estranha defesa da produção de receitas, aproveita-se do mal para constituir uma condição material razoável e útil na manutenção dos laços sociais. Para Rousseau, o Estado deve aproveitar-se dessa mentalidade, pois ela possibilita adquirir um rendimento garantido e seguro. Um rendimento conseguido justamente "sobre esta distinção" (Rousseau, 1964a, p.277). A estranheza só não é maior, porém, quando pensamos em quem será o principal beneficiário dessa política econômica, o desenvolvimento da indústria. Ao mesmo tempo que reanima a agricultura, a tributação sobre "as coisas de luxo" assegura a industrialização e o seu processo emergente nos países da Europa Ocidental: "Pela mesma razão, a indústria não tem nada a sofrer em uma ordem econômica que enriquecesse as finanças, reanimasse a agricultura, subsidiando o agricultor, e reaproximasse progressivamente todas as fortunas dessa mediania que faz a verdadeira força de um Estado" (Rousseau, 1964a, p.258). Segundo Rousseau, a força da lei só pode agir plenamente sobre a mediocridade. Nesse sentido, contrariando muitas das correntes interpretativas de seu discurso, o genebrino não parece rejeitar a atividade secundária da economia, mas aprovar os benefícios que uma tal ordem econômica pode trazer à sua implantação. ${ }^{13}$ No fundo, o fortalecimento da atividade primária da economia permitiria a prosperidade industrial do país: a agri-

\footnotetext{
12 É preciso considerar o seguinte, o espetáculo em geral para Rousseau é somente um entretenimento sem nenhuma função moral aparente: "Quant à l'espèce des Spectacles, c'est necessairement le plaisir qu'ils donnent, et non leur utilité, qui la détermine. Si l'utilité peut s'y trouver, à la bonne heure; mais l'objet principal est de plaire, et, pourvu que le Peuple s'amuse, cet objet est assez rempli" (Rousseau, 1995, p.16-7). Para o autor, há apenas três tipos de meios com que podemos agir sobre os costumes de um povo: a força das leis, o império da opinião e a atração do prazer. (Ibidem, p.20-1).
} 
cultura, na ótica de Rousseau, seria um elemento fundamental para o seu desenvolvimento.

$\mathrm{O}$ autor conclui suas propostas com os possíveis benefícios dessa cobrança de tributos sobre o supérfluo. Ela reduz o desequilíbrio da riqueza a uma média justa, e isso de dois modos: primeiro, através da renúncia às despesas desnecessárias por parte dos privilegiados. Embora num primeiro momento ocorra um decréscimo na arrecadação fiscal, fruto da diminuição das contribuições, a soma geral é favorável aos cofres públicos, pois o Estado acaba por desembolsar menos com as importações dos bens de consumo. Segundo, se os ricos não dispensam as suas prodigalidades, motivo dos desejos e prazeres que movimentam o amor próprio, o erário deve encontrar no produto mesmo dos impostos os recursos necessários para atender o mínimo necessário à sobrevivência do Estado; numa hipótese nem tão remota, talvez, também provocar o enriquecimento indispensável para o progresso industrial. O Estado, afinal, enriquece com a "despesa inútil dos particulares" (Rousseau, 1964a, p.277). ${ }^{14}$ A exigência é a mesma para ambos, aplicar uma política fiscal sem ferir o direito de propriedade e o interesse da nação. Se, por um lado, a tributação não pode ser imposta sem o consentimento expresso do povo e de seus representantes, por outro lado, isso só é válido para as coisas de uso estritamente necessário que estejam diretamente ligadas ao direito de propriedade. Já sobre as coisas que podem ser "interditadas" quanto ao seu uso, não é mais preciso o consentimento geral, pois a sua fruição é optativa e de natureza reservada aos indivíduos e o consumidor "deseja" pagar por ela. Ao governante, vale dizer, basta uma determinação particular proibindo ou não o seu desfrutar. Em alguns casos, porém, o consentimento popular está pressuposto. A razão desse argumento é simples, o que o governo pode vedar, mas não é proibido pelas leis e nem está contra os costumes, ele pode permitir por meio de um direito: "Se, por exemplo, o governo pode proibir o uso das carruagens, pode, com muito mais razão, impor uma taxa sobre elas; constitui isso um meio sábio e útil de censurar o seu uso sem fazê-lo cessar" (Rousseau, 1964a, p.278). A taxa

13 Neste ponto, a argumentação de María José Villaverde (1987, p.145) parece equivocada. A autora não se dá conta das sutilezas do discurso rousseauniano, posicionando-se, infelizmente, numa relação dicotômica entre passado e futuro. Rousseau seria um defensor, é claro, do passado; um defensor das agriculturas de sobrevivência contra o emergente modo de produção capitalista.

14 Robert Derathé (1964, p.LXXX) sustenta uma posição diferente da minha; para ele Rousseau está mais preocupado em "reduzir as despesas do Estado do que em aumentar os seus recursos". 
transforma-se em uma espécie de multa compulsória, cujo efeito é frear o consumo exagerado dos cidadãos abastados.

SAHD, L. F. N. de A. e S. Rousseau and the administration of goods. Trans/Form/Ação, (São Paulo), v. 26, p.141-159, 2003.

$n$ ABSTRACT: The work emphasizes the importance of the rules of the art of government in Rousseau's political thought; in particular, those rules that keep the administration machinery working.

n KEYWORDS: Popular sovereignty; economy; private property; fiscal theory.

\section{Referências bibliográficas}

BESSE, G. Jean-Jacques Rousseau, l'apprentissage de l'humanité. Paris: Messidor/Sociales, 1988.

BONNEY, R. Système économiques et finances publiques. Paris: PUF/CNL, 1996.

COLLETTI, L. Ideologia e società. 4.ed. Roma-Bari: Laterza, 1975.

DERATHÉ, R. Introduction. In: ROUSSEAU, J.-J. Euvres Complètes. Tomo III. Paris: Pléiade, Gallimard, 1964.

GOLDSCHMIDT, V. Anthropologie et politique. 2.ed. Paris: Vrin, 1983.

LARRÈRE, C. L'invention de l'économie au XVIIIe siècle. Paris: PUF, 1992.

LOCKE, J. Two Treatises of Government. Cambridge: Cambridge University Press, 1996.

MONTESQUIEU. De l'esprit des lois. In: Euvres Complètes. Tomo II. Paris: Pléiade, Gallimard, 1951.

PHILONENKO, A. Jean-Jacques Rousseau et la pensée du malheur. Volume I. Paris: Vrin, 1994.

RILEY, P. The General Will before Rousseau. Princeton: Princeton University Press, 1986.

ROUSSEAU, J.-J. Discours sur l'économie politique. In: Euvres Complètes. Tomo III. Paris: Pléiade, Gallimard, 1964a.

. Du contrat social. In: . Euvres Complètes. Tomo III. Paris: Pléiade, Gallimard, 1964b.

. Fragments politiques. In: Euvres Complètes. Tomo III. Paris:

Pléiade, Gallimard, 1964c. 
Lettres écrites de la montagne. In:

Cuvres Complètes. Tomo

III. Paris: Pléiade, Gallimard, 1964d.

Projet de constitution pour la Corse. In:

Tomo III. Paris: Pléiade, Gallimard, 1964e.

. Euvres Complètes.

. Considérations sur le gouvernement de Pologne. In:

Euvres

Complètes. Tomo III. Paris: Pléiade, Gallimard, 1964f.

ROUSSEAU, J.-J. Emile ou de l'éducation. In:

Tomo IV. Paris: Pléiade, Gallimard, 1969.

Cuvres Complètes.

. Lettre à M. d'Alembert. In:

. Euvres Complètes. Tomo V. Paris:

Pléiade, Gallimard, 1995.

Première esquisse et fragments de l'article Économie politique. In: . Euvres Complètes. Tomo II. Paris: l'Intégrale, Seuil, 1971.

SCHUMPETER, J. A. History of Economic Analysis. London: George Allen \& Unwin, 1954.

SOBOUL, A. La Révolution française. Paris: Tel/Gallimard, 1984.

VILLAVERDE, M. J. Rousseau y el pensamiento de las luces. Madrid: Tecnos, 1987. 